UDC 808.51:81.42

DOI https://doi.org/10.32838/2710-4656/2021.3-1/22

Humeniuk N. H.

Borys Grinchenko Kyiv University

\title{
PRAGMATIC ASPECT OF THE QUEEN ELIZABETH II CHRISTMAS 2020 MESSAGE (12.25.2020)
}

The following work is devoted to problems of the Queen Elizabeth II Christmas 2020 discourse pragmatic features. The Queen Elizabeth II Christmas 2020 discourse is defined in the given work as a declarative discourse with the purpose of Queen Elisabeth II to express Her Majesty's congratulations and wishes for the inhabitants the UK and the Commonwealth realm on the Jesus Christ Birth occasion, as well as an argumentative discourse to analyze and make conclusions of the passing over year, to draw the plans and guide lines of the forthcoming year and to convince the interlocutor (the inhabitants of the UK and Commonwealth realm) in the correctness of these conclusions and plans to act in the way proposed by Queen Elizabeth II. It is stressed that the given discourse is organized by Queen Elizabeth II with the purpose to orient the inhabitants of UK and Commonwealth realm for Christian life in 2021, full of love, hope and support to each other, full of respect to people of different cultures, traditions and believes. It is pointed out that the ideas of the community being united, of the community tolerance and personal contribution, even personal readiness for sacrificing, are the main ideas of Her Majesty Christmas 2020 message. It is stressed that the situation layout, the video and photo materials, the image plans and music are used to achieve the purposes of the Queen Elizabeth II Christmas 2020 discourse by creating the semiofficial and private, elevated and calm, magic and symbolic atmosphere of the given discourse. It is stated that argumentative tactics, the appealing to act tactics are used within the Queen Elizabeth II Christmas 2020 discourse. It is pointed out that orientation on the Jesus life, on the heroic deeds of national personalities, on Her Majesty readiness to serve the community, as well as on Jesus teaching in the form of parables are helpful to achieve the pragmatic purposes of the Queen Elizabeth II Christmas 2020 discourse.

Key words: Queen Elizabeth II Christmas 2020 discourse, argumentative tactics, appealing to act tactics, extra-linguistic factors, message.

Problem statement. The problems of modern life, full of challenges, is a focus of national and global elite. Manifestly, the challenging time of COVID is reflected within the annual traditional speeches of statesmen, devoting to the national, religious or state holidays. In this case, Christmas as a global Christian holiday of Jesus Christ Birth has the signs, the marks of the challenging time of COVID in the speech of the UK and Commonwealth realm sovereign - Queen Elizabeth II.

The Queen Elizabeth II Christmas 2020 speech to the nation with the analysis of the problems to decide as well as with the Her Majesty proposed ways to overcome these problems is a focus of the given work.

In other words, the purpose of the given work is to make a survey and studying of the pragmatic features of the Queen Elizabeth II Christmas 2020 discourse, which is possible to achieve with the help of the several methods usage: discourse analysis method, method of simple calculation, pure sampling and comparative method, method of immediate constituents.
Literature review. The given work makes its contribution to the further discourse investigations $[1 ; 6 ; 7 ; 10]$.

It continues a series of research findings dealing with the discourses of national and global elite with a focus on the pragmatic purposes of their creators $[2 ; 3]$ as well as an attempt to make findings of the Queen Elizabeth II discourses with the pragmatic purposes of Her Majesty [4; 5; 9].

The aim of the paper is to make a survey of the pragmatic features of the Queen Elizabeth II Christmas 2020 speech to the nation with the purpose of Her Majesty to congratulate the inhabitants of the UK and the Commonwealth realm with the Day of Jesus Christ Birth, to make analysis of the passing over year and make up the future plans of the forthcoming year in the life for the UK and Commonwealth realm community. Making the survey of the pragmatic features of the Queen Elizabeth II Christmas 2020 discourse presupposes the differentiation of the discourse strategies and tactics. 
The material of the article. Traditionally, Queen Elisabeth II sends Her Christmas message to the nation to congratulate the inhabitants of the UK and the Commonwealth realm with one of the most important holidays for Christians - the Day of Jesus Christ Birth - and to express Her wishes for them in this occasion. Traditionally, Her Majesty Christmas message contains the analysis of the passing over year in the life of the UK community and future plans of the forthcoming year.

The Queen Elisabeth II Christmas 2020 message was recorded in Windsor Castle and broadcasted by $\mathrm{TV}$, radio, internet on the 25-th of December, 2020.

In our work we differentiate the annual Queen Elisabeth II Christmas message as a declarative discourse with the purpose of Queen Elisabeth II to express Her Majesty's congratulations and wishes for the inhabitants the UK and the Commonwealth realm on the Jesus Christ Birth occasion as well as an argumentative discourse to analyze and make conclusions of the passing over year, to draw the plans and guide lines of the forthcoming year and to convince the interlocutor (the inhabitants of the UK and Commonwealth realm) in the correctness of these conclusions and plans to act in the way proposed by Queen Elizabeth II.

We consider that the Queen Elisabeth II Christmas 2020 message has the features of declarative, argumentative and appealing to act discourse.

The Queen Elizabeth II Christmas 2020 discourse is prepared beforehand, recorded and later broadcasted in the form of monologue. In other words, it is virtual discourse, created artificially and imitating the natural communication in the form of monologue.

Normatively, the given discourse contains the text of message itself, known as linguistic factor, and factors defining the given situation known as extra-linguistic factors.

It is known that extra-linguistic factors play the great role in discourse realization. So, the setup, as one of extra-linguistic factors, of the Queen Elizabeth II Christmas 2020 discourse plays the great role in its realization. It is very important "from what she wears, to what music is heard and what images and footage are shown, every aspect of the speech has the capacity to affect how it is received" [8].

The layout, the set-up of the Queen Elizabeth II Christmas 2020 discourse is highly predictable because of its annual repeated matter as well as of the nature of the event to celebrate. But each Christmas message of the Queen Elizabeth II is unique because of its informative essence and valuable ideas, as well as of its organization as a certain art masterpiece with its elements of décor, music, photo, video materials.

Thus, the situation of the Queen Elizabeth II Christmas 2020 discourse is semi-official, but solemn and elevated.

The message is starting with the national anthem of the UK and of some countries of the Commonwealth realm, as well as of the Royal family "God Save the King/Queen". The anthem is played by the band on horses and in uniforms within the territory of Windsor Castle, which is a royal residence. The presence of the Royal Standard flying at royal residence, demonstrating that the sovereign is present, and the central sign "the Queen" make the given situation official, solemn and elevated.

The situation is transforming its official tone into semi-official one by the Queen Elizabeth II Queen delivering her message from "the Green Drawing Room of Windsor Castle, which was the same location as last year, but the staging was very different" [8].

Queen in purple dress with diamonds and broche on the background of Christmas tree with lights which is a constant attribute of Christmas Holiday, makes the given situation magic and symbolic, solemn and elevating.

Her Majesty sitting near the table with a sheet of paper, silver box and a flowerpot with blossoming flowers, with the photo of her husband Prince Philip, "not dressed for a royal occasion but wearing an ordinary-looking blue jumper" [8] and the dark green curtains with the daily light through the window make the given situation calm and private.

At the same time the given situation with Queen Elizabeth II on the background of the daily light through the window and the lights of Christmas tree is rather symbolic. The daily light through the window symbolizes Jesus Christ, who came to Earth to save the people from the sin, being crucified and resurrected, given them chance, given them hope to join and become part of eternity. In this context, the Christmas lights symbolize the people of the UK and Commonwealth realm community and their own contribution to the national and global goodness, to the mutual victory of good over evil. The position of Queen Elizabeth II is intermediate between the Christmas lights and the daily light of the window, which is also symbolic, pointing out Her Majesty role as God mediator, as God agent with emphasis on Her responsibility and liability for the people, which were given Her Majesty by God Jesus Christ, as well as Her own contribution for the mutual deeds of good.

The other extra-linguistic factor which plays the great role in the Queen Elizabeth II Christmas 
2020 discourse realization is the factor of music. Music is used three times within Her Majesty Christmas 2020 message: the band playing "God Save the Queen" to make the situation official and solemn at the beginning of the message; the playing of the bagpipes (an ancient type of instrument) to make the situation solemn, but touching and sad in the middle of the message, while commemorating the Tomb of the Unknown Warrior in the Westminster Abbey; the singing of the Christmas carol by the Lewisham and Greenwich NHS Choir to make the situation solemn, elevating and joyful at the end of the message like a final holiday chord of it.

The other extra-linguistic factor which plays the great role in the Queen Elizabeth II Christmas 2020 discourse is the factor of using photo and video materials to make the information of the message more vital and vivid, to emphasize the main ideas of the message. Totally, the video material is used four times and photos are used three times within the Queen Elizabeth II Christmas 2020 discourse, and one time photo and video materials are used as a combination to make the final part of the message more informative, expressive and evidential.

All the photo and video materials are given in the nearest contact with the content of the message. The first video block is devoted to the problems of volunteering activity in the countries of the Commonwealth during the period of coronavirus pandemic in 2020.

Across the Commonwealth, my family and I have been inspired by stories of people volunteering in their communities, helping those in need [9].

The second one is connected with the 200th anniversary of the birth of the nurse Florence Nightingale and the contribution of the UK medical front-line services during the coronavirus pandemic in 2020:

1. This year, we celebrated International Nurses' Day, on the $200^{\text {th }}$ anniversary of the birth of Florence Nightingal [9].

2. Today, our front-line services still shine that lamp for us - supported by the amazing achievements of modern science - and we owe them a debt of gratitude [9].

The third video block demonstrates another event in the life of the UK and the Commonwealth realm the commemoration of the Unknown Warrior in Westminster Abbey:

In November, we commemorated another hero - though nobody knows his name. The Tomb of the Unknown Warrior isn't a large memorial, but everyone entering Westminster Abbey has to walk around his resting place... [9].
The fourth video block, being a combination of the Lewisham and Greenwich NHS Choir Christmas carol singing and information about the happy moments of the Royal family and the UK inhabitants in 2020, united with the photo material of the happy and touching moments for the UK people in 2020, who belong to the different social, religious, cultural groups, makes the given message joyful, full of harmony, hope and love:

Joy to the world! Lord has come! Lets Earth receive Its King... [9].

All the video materials within the Queen Elizabeth II Christmas 2020 discourse have their specific features. Firstly, being devoted to some problems, they contain the materials of the people natural interaction, as well as of virtual communication with the help of video conferences, which became common during the coronavirus isolation in 2020. Secondly, all the video materials contain information of the Royal family contribution to the UK and the Commonwealth realm community deeds during 2020 .

The other extra-linguistic factor which plays the great role in the Queen Elizabeth II Christmas 2020 discourse is the factor of the image plan usage. So, the far, the middle and the closest (the nearest) plan images are used to realize the pragmatic purpose of the speaker. The far image plan is used twice: at the beginning of message to introduce the theme of discussion - the celebration of Christmas (1), and in the middle of the message to introduce the final part of Queen Elizabeth II speech with Her conclusions, and wishes and desires for all the community of the UK and commonwealth realm in 2021, which starts with some sad events of commemoration of the Unknown Warrior in Westminster Abbey (2):

1. Every year we herald the coming of Christmas by turning on the lights [9].

2. ...honouring this unnamed combatant of the First World War a symbol of selfless duty and ultimate sacrifice [9].

The peculiar feature of the far image plan usage within the Queen Elizabeth II Christmas 2020 discourse is its gradually transformation to the middle plan image, which is predominantly used within Her Majesty Christmas 2020 speech. In this context, the closest plan image is used once, at the end of the message, to emphasize the final part of it, to make it the strongest element of all the speech:

It is in that spirit that I wish you a very happy Christmas [9].

So, all the extra-linguistic factors of layout, music, video material, photos, image plans are used in the closest contact with the message itself to real- 
ize the pragmatic purposes of the Queen Elizabeth II Christmas 2020 speech - to congratulate the inhabitants the UK and the Commonwealth with Christmas, make conclusions of 2020, to draw the plans of 2021.

As it was mentioned above, being the declarative discourse, the Queen Elizabeth II Christmas 2020 speech contains Her Majesty congratulations and wishes for the inhabitants of the UK and Commonwealth realm:

It is in that spirit that I wish you a very happy Christmas [9].

As an argumentative discourse, in Her Christmas 2020 message Queen Elizabeth II uses the argumentative tactics to realize the pragmatic purposes - to influence the inhabitants of the UK and Commonwealth realm to act in the way Her Majesty proposes.

It is known that argumentative tactics presuppose analysis, synthesis, giving arguments, making conclusions and proposing decisions. In its turn, analysis presupposes drawing of negative and positive, weak and strong peculiarities of the phenomenon under analysis, as well as its advantages and disadvantages.

Thus, making analysis of the 2020 year going away, Queen Elizabeth II tries to avoid its negative assessment, focusing only on the idea of challenging year. Its problems of the coronavirus disease (1) and of the religious, socio-cultural distance (2), which are vulnerable and of great importance for the inhabitants of the UK and Commonwealth realm, receive the form of Her Majesty slant on them:

1. For Christians, Jesus is the light of the world, but we can't celebrate his birth today in quite the usual way [9].

2. People of all faiths have been unable to gather as they would wish for their festivals, such as Passover, Easter, Eid, and Vaisakhi, but we need life to go on [9].

Making analysis of the year 2020, Queen Elizabeth II makes several conclusions. The first conclusion is that the challenging time of coronavirus made people closer expressing their support and help to each other:

1. Remarkably, a year that has necessarily kept people apart has in many ways brought us closer [9].

2. Across the Commonwealth, my family and I have been inspired by stories of people volunteering in their communities, helping those in need [9].

The second one is that the medical services showed the examples of the high level support for the population during the coronavirus pandemic:

Today, our front line services still shine that lamp for us, supported by the amazing achievements of modern science. And we owe them a debt of gratitude [9].

As for the urgent problem of religious and cultural distance, Queen Elizabeth II makes the conclusion that people of all faith should be united because of the common problems to decide - the problem of coronavirus overcoming:

People of all faiths have been unable to gather as they would wish for their festivals, such as Passover, Easter, Eid, and Vaisakhi [9].

In order to stress the idea of social, religious and cultural tolerance to all the inhabitants of the UK and Commonwealth realm Her Majesty demonstrates the parable of the Good Samaritan, which is given from Bible, which was taught by Jesus. According to the parable "the man who is robbed and left at the roadside, later saved by someone who did not share his religion or culture" [9].

Demonstrating this parable Queen Elizabeth II tries to stress the idea that people of other faith, living within the Christian community of the UK and Commonwealth realm, fulfill the role of their neighbors, whose presence does not contradict the Christian religion dogmas, but it is a necessary factor of Christian love and patience to people of different social groups, cultures and religions, as all the people are equal in the eyes of God:

This wonderful story of kindness is still as relevant today. Good Samaritans have emerged across society showing care and respect for all, regardless of gender, race or background, reminding us that each one of us is special and equal in the eyes of God [9].

So, the conclusions of Queen Elizabeth receive the character of the main message ideas: necessity of nation's unity and tolerance within the UK and Commonwealth realm community.

The other important idea of the Queen Elizabeth II Christmas 2020 speech is the idea of individual contribution to the UK and Commonwealth realm community.

For Christians, the life of Jesus Christ is an example of love, hope and sacrifice for all the people of the Earth, it is an etalon which people should orient their lives:

1. For Christians, Jesus is 'the light of the world' [9].

2. The teachings of Christ have served as my inner light, as has the sense of purpose we can find in coming together to worship [9].

In order to prove the idea of selflessness, of individual responsibility for the community Queen Elizabeth II demonstrates 2 very important events for the UK and Commonwealth realm community the 200th anniversary of the birth of nurse Florence 
Nightingale (1) and the commemoration of the Tomb of the Unknown Warrior (2):

1. This year, we celebrated International Nurses' Day, on the 200th anniversary of the birth of Florence Nightingale. As with other nursing pioneers like Mary Seacole, Florence Nightingale shone a lamp of hope across the world [9].

2. In November, we commemorated another hero - though nobody knows his name. The Tomb of the Unknown Warrior isn't a large memorial, but everyone entering Westminster Abbey has to walk around his resting place, honouring this unnamed combatant of the First World War - a symbol of selfless duty and ultimate sacrifice [9].

Orientation on the national heroes within the Queen Elizabeth II Christmas 2020 discourse makes it possible to achieve Her Majesty pragmatic purposes - to orient the inhabitants of the UK and Commonwealth realm for Christian life full of love, support and hope, full of selflessness, even readiness to personal sacrifice for the community.

In this case, Her Majesty expresses her readiness to make Her own contribution for the community during the challenging time of coronavirus by supporting people in need in Her Majesty praying and thoughts:

Of course, for many, this time of year will be tinged with sadness: some mourning the loss of those dear to them, and others missing friends and family-members distanced for safety, when all they'd really want for Christmas is a simple hug or a squeeze of the hand. If you are among them, you are not alone and let me assure you of my thoughts and prayers [9].
Orientation on the Jesus life, on the heroic deeds of national personalities, on Her Majesty readiness to serve the community, as well as on Jesus teaching in the form of parable about Good Samarian makes it possible to use another tactics - appealing to act tactics, which contains an appeal to live and have the spirit of love, hope and selflessness:

Let the light of Christmas - the spirit of selflessness, love and above all hope-guide us in the times ahead [9].

Conclusions. Summing up the material, it is important to state that Queen Elizabeth II Christmas 2020 discourse as a unity of content and form contains the pragmatic purposes of its creator: to express congratulations and wishes of Her Majesty to the inhabitants of the UK and Commonwealth realm on the occasion of Jesus Christ Birthday; to make conclusions of 2020 year and to make up plans for 2021. Using the argumentative tactics, making analysis of 2020 year as a challenging year of coronavirus disease and of some cultural-religious problems, Her Majesty tries to orient the inhabitants of UK and Commonwealth realm for Christian life in 2021, full of love, hope and support to each other, full of respect to people of different cultures, traditions and believes. The ideas of the community being united, of the community tolerance and personal contribution, even personal readiness for sacrificing, are the main ideas of Her Majesty Christmas 2020 message.

It is perspective to pay attention to the stylistic features of the given discourse, to the Queen Elisabeth II individual style of their usage.

\section{References:}

1. Grice H. P. Logic and Conversation. Syntax and semantics : in 3 vol. / P. Cole, J. L. Morgan (eds.). New York : Academic Press, 1975. Vol. 3 : Speech acts. P. 41-58.

2. Humeniuk N. G. Pragma-communicative aspect of the Boris Johnsons' first speech as a Prime Minister (July 24, 2019). Закарпатські філологічні студії. 2019. Вип. 12. С. 68-74.

3. Humeniuk N. G. Pragmatic features of the UK Prime Minister Question Time discourse, 09.04.2019. Науковий вісник Херсонського державного університету. Серія «Германістика та міжкультурна комунікація». 2020. Вип. 1. С. 9-14.

4. Humeniuk N. G. Stylistic aspect of the Queen Elizabeth II coronavirus discourse (04.05.2020). Вчені записки Таврійського національного університету імені В.І. Вернадського. Серія "Філологія. Соціальні комунікаиії». 2020. Т. 31(70). № 4. Ч. 2. С. 52-56.

5. Humeniuk N. G. Storytelling Technique within the Queen Elizabeth coronavirus discourse, 04.05.20. Hayковий вісник Дрогобиџького державного педагогічного університету імені Івана Франка. Серія «Філологічні науки (мовознавство)». 2020. № 14. С. 36-39.

6. Lakoff R. The logic of politeness: Or, minding your p's and q's. Papers from the 9th Regional Meeting of the Chicago Linguistic Society / C. Corum, T. Cedric Smith-Stark, A. Weiser (eds.). Chicago : Chicago Linguistic Society, 1973. P. 292-305.

7. Leech G. N. Principles of pragmatics. London : Longman, 1983. 250 p.

8. Murphy V. All The Spoken and Unspoken Messages in Queen Elizabeth's Christmas Day Broadcast. URL: https://www.townandcountrymag.com/society/tradition/a35076614/queen-elizabeth-brooch-prince-philipchristmas-day-broadcast-2020-analysis/. 
9. Queen Elizabeth II Christmas Broadcast Speech Transcript 2020. URL: https://www.rev.com/blog/ transcripts/queen-elizabeth-ii-christmas-broadcast-speech-transcript-2020.

10. Van Dijk T., Kintsch W. Strategies of Discourse Comprehension. New York : Academic Press, 1983. 389 p.

\section{ГУМеНюК Н. Г. ПРАГМАТИЧНИЙ АСПЕКТ РІЗДВЯНОГО 2020 ПОСЛАННЯ КОРОЛЕВИ ЄЛИЗАВЕТИ ІІ (25.12.2020)}

Статтю присвячено розгляду прагматичних особливостей Різдвяного 2020 дискурсу Королеви Єлизавети II. Різдвяний 2020 дискурс Королеви Єлизавети визначено в роботі як декларативний дискурс, метою якого є прагнення Королеви Слизавети II висловити привітання й побажання мешканиям Сполученого Королівства та краӥн Співдружності з нагоди народження Ісуса Христа, а також як аргументивний дискурс для проведення аналізу та формулювання висновків за рік, ще минув, складання планів та орієнтирів на майбутній рік і переконання співрозмовників (жителів Великобританії та краӥн Співдружності) у правильності иих висновків і планів діяти у спосіб, запропонований королевою Єлизаветою II. Підкреслюється, щุо поданий дискурс організовано Королевою Єлизаветою II з метою зорієнтувати мешканиів Великобританії та країн Співдружсності на християнське життя у 2021 рочі, сповнене любові, надії, підтримки один одного, поваги до представників інших культур, традииій і переконань. Варто зазначити, що єдність та толерантність у суспільстві, вагомість персонального внеску, навіть готовність до самопожертви є основними ідеями Різдвяного 2020 послання Ї̈ Величності. Зазначається, що ситуаційне оформлення, відео- та фотоматеріали, використання музики і планів зображення сприяють досягненню прагматичних намірів Королеви Єлизавети II в дискурсі Різдвяного 2020 послання Ї̈ Величності за рахунок створення напівофіційної та приватної, піднесеної і спокійної, магічної та символічної атмосфери поданого дискурсу. Зауважено, щуо в Різдвяному 2020 дискурсі Королеви Слизавети II використовуються аргументативна тактика та тактика заклику до дій. Вказано на те, що орієнтація на життя Ісуса Христа, на національні персоналії, на готовність Ї̈ Величності служити спільноті, на вчення Ісуса Христа у формі притч сприяє досягненню прагматичних намірів Королеви Єлизавети II в Різдвяному 2020 дискурсі.

Ключові слова: Різдвяний 2020 дискурс Королеви Єлизавети II, аргументативна тактика, тактика заклику до дій, екстралінгвістичні фактори, послання. 